\title{
ORIGINAL
}

\section{Clinical characteristics and day-90 outcomes of 4244 critically ill adults with COVID-19: a prospective cohort study}

\author{
COVID-ICU Group on behalf of the REVA Network and the COVID-ICU Investigators ${ }^{*}$
}

(c) 2020 Springer-Verlag GmbH Germany, part of Springer Nature

\begin{abstract}
Purpose: To describe acute respiratory distress syndrome (ARDS) severity, ventilation management, and the outcomes of ICU patients with laboratory-confirmed COVID-19 and to determine risk factors of 90-day mortality post-ICU admission.

Methods: COVID-ICU is a multi-center, prospective cohort study conducted in 138 hospitals in France, Belgium, and Switzerland. Demographic, clinical, respiratory support, adjunctive interventions, ICU length-of-stay, and survival data were collected.

Results: From February 25 to May 4, 2020, 4643 patients (median [IQR] age 63 [54-71] years and SAPS II 37 [28-50]) were admitted in ICU, with day-90 post-ICU admission status available for 4244. On ICU admission, standard oxygen therapy, high-flow oxygen, and non-invasive ventilation were applied to $29 \%, 19 \%$, and $6 \%$ patients, respectively. 2635 (63\%) patients were intubated during the first $24 \mathrm{~h}$ whereas overall 3376 (80\%) received invasive mechanical ventilation (MV) at one point during their ICU stay. Median (IQR) positive end-expiratory and plateau pressures were $12(10-14) \mathrm{cmH}_{2} \mathrm{O}$, and $24(21-27) \mathrm{cmH}_{2} \mathrm{O}$, respectively. The mechanical power transmitted by the $\mathrm{MV}$ to the lung was 26.5 (18.6-34.9) $\mathrm{J} / \mathrm{min}$. Paralyzing agents and prone position were applied to $88 \%$ and $70 \%$ of patients intubated at Day-1, respectively. Pulmonary embolism and ventilator-associated pneumonia were diagnosed in 207 (9\%) and 1209 (58\%) of these patients. On day 90, 1298/4244 (31\%) patients had died. Among patients who received invasive or noninvasive ventilation on the day of ICU admission, day-90 mortality increased with the severity of ARDS at ICU admission (30\%, 34\%, and 50\% for mild, moderate, and severe ARDS, respectively) and decreased from 42 to $25 \%$ over the study period. Early independent predictors of 90-day mortality were older age, immunosuppression, severe obesity, diabetes, higher renal and cardiovascular SOFA score components, lower $\mathrm{PaO}_{2} / \mathrm{FiO}_{2}$ ratio and a shorter time between first symptoms and ICU admission.
\end{abstract}

Conclusion: Among more than 4000 critically ill patients with COVID-19 admitted to our ICUs, 90-day mortality was $31 \%$ and decreased from 42 to $25 \%$ over the study period. Mortality was higher in older, diabetic, obese and severe ARDS patients.

Keywords: Acute respiratory distress syndrome, Mechanical ventilation, COVID-19, Outcome, Mortality risk factor 


\section{Introduction}

From March to May 2020, Europe was massively affected by the coronavirus disease 2019 (COVID-19) outbreak. In that context, the REVA network [1] designed a specific registry (COVID-ICU), to prospectively collect characteristics, management, and outcomes of patients admitted to intensive care units (ICUs) for severe COVID-19 in France, Belgium, and Switzerland. In France, as of October 1st, 2020, 395,104 patients had been tested positive for severe acute respiratory syndrome coronavirus 2 (SARS-CoV-2) and 32,365 deaths have been associated with the disease. On April 8, 2020, the number of COVID-19 patients hospitalized in French ICUs peaked at 7148 .

A few case-series [2-5] have described baseline characteristics and short-term mortality (up to 28-days after ICU admission) ranging from 26 to more than $50 \%$ in critically ill patients with COVID-19. However, recovery from severe COVID-19 often takes several weeks and a substantial number of these patients were still in the ICU or the hospital at the time their outcome was evaluated $[4,5]$. Notably, 28 -day mortality was $41 \%$ in the control care group of the RECOVERY trial, which showed that dexamethasone improved the survival of patients receiving invasive mechanical ventilation or oxygen at randomization [6].

The present study reports data of 4244 patients with laboratory-confirmed SARS-CoV-2 infection admitted to the ICU and for whom day-90 status was available. We also evaluated risk factors associated with 90-day mortality in these critically ill patients.

\section{Methods}

\section{Study Design, Patients}

COVID-ICU is a multi-center, prospective cohort study conducted in 149 ICUs from 138 centers, across three countries (France, Switzerland, and Belgium). Centers were invited to participate by public announcements and by the Reseau European de recherche en Ventilation Artificielle (REVA) network (70 centers were active members of this network). We included in the present report data from participating ICUs that had enrolled at least one patient with complete data on age and 90-day vital status. COVID-ICU received approval from the ethical committee of the French Intensive Care Society (CESRLF 20-23) in accordance with our local regulations. All patients or close relatives were informed that their data were included in the COVID-ICU cohort.

All consecutive patients over 16 years of age admitted to the participating ICU between February 25, 2020, and May 4, 2020, with laboratory-confirmed severe acute respiratory syndrome coronavirus 2 (SARS-CoV-2)

\section{Take-home message}

In this cohort study that included 4244 adult patients with severe acute respiratory syndrome coronavirus 2 (SARS-CoV-2) infection admitted to the ICU, $80 \%$ received invasive mechanical ventilation. Mortality 90 days after ICU admission was 31\% in the whole cohort and $37 \%$ in the subgroup of patients who received invasive mechanical ventilation on the day of ICU admission. Among these patients with early intubation, mortality increased with the severity of ARDS at ICU admission (30\%, 34\%, and 50\% for mild, moderate, and severe ARDS, respectively).

infection were included. Laboratory confirmation for SARS-CoV-2 was defined as a positive result of real-time reverse transcriptase-polymerase chain reaction (RTPCR) assay from either nasal or pharyngeal swabs, or lower respiratory tract aspirates [7]. Patients without laboratory-confirmed COVID-19 were not included, even if they presented with a typical radiological pattern.

Inclusions were stopped on May 4, 2020, after enrollment of 4643 patients admitted to the ICU. Survival status up to 90 days after ICU admission was obtained for 4244 of them.

\section{Data collection}

Day 1 was defined as the first day when the patient was in ICU at $10 \mathrm{am}$. Each day, the study investigators completed a standardized electronic case report form. Baseline information collected at ICU admission were: age, sex, body mass index (BMI), active smoking, Simplified Acute Physiology Score (SAPS) II score [8], Sequential Organ Failure Assessment (SOFA) [9], comorbidities, immunodeficiency (if present), clinical frailty scale [10], date of the first symptom, dates of the hospital and ICU admissions. The case report form prompted investigators to provide a daily-expanded data set including respiratory support devices (oxygen mask, high flow nasal cannula, or non-invasive ventilation), mechanical ventilation settings (positive end-expiratory pressure (PEEP), the fraction of inspired oxygen $\left(\mathrm{FiO}_{2}\right)$, respiratory rate, tidal volume, plateau pressure, arterial blood gas, standard laboratory parameters, and adjuvant therapies for acute respiratory distress syndrome (ARDS) such as the use of continuous neuromuscular blockers, nitric oxide, prone position, corticosteroids, or extracorporeal membrane oxygenation until day-90. Driving pressure was defined as plateau pressure minus PEEP and mechanical power $(\mathrm{J} / \mathrm{min})$ was calculated as follows: Mechanical power $(\mathrm{J} / \mathrm{min})=0.098 \times$ tidal volume $\times$ respiratory rate $\times$ (peak pressure $-1 / 2 \times$ driving pressure) [11]. If not specified, peak pressure was considered equal to plateau pressure. Ventilatory ratio was defined 
as (minute ventilation $\times \mathrm{PaCO}_{2}$ ) - (predicted bodyweight $\times 100 \times 37.5)[12]$.

\section{ARDS severity, complications, and outcomes}

ARDS was graded based on the Berlin definition for patients undergoing mechanical ventilation (invasive or non-invasive) on ICU day 1 [13]. Patients on nasal, mask or high-flow oxygen therapy were not included in this group. However, their day- $1 \mathrm{PaO}_{2} / \mathrm{FiO}_{2}$ was calculated by converting $\mathrm{O}_{2}$ flow to estimated $\mathrm{FiO}_{2}$ (see conversion tables in the supplement) [14]. ICU-complications and organ dysfunction included acute kidney failure requiring renal replacement therapy, thromboembolic complications (distal venous thrombosis or proven pulmonary embolism by either pulmonary CT angiography or cardiac echography), ventilator-associated pneumonia, and cardiac arrest. Clinical suspicion of ventilator-associated pneumonia was confirmed before antibiotics either by quantitative distal bronchoalveolar lavage cultures growing $\geq 10^{4} \mathrm{cfu} / \mathrm{mL}$, blind protected specimen brush distal growing $\geq 10^{3} \mathrm{cfu} / \mathrm{mL}$, or endotracheal aspirates growing $\geq 10^{6} \mathrm{cfu} / \mathrm{mL}$.

Patient outcomes included the date of liberation from mechanical ventilation, dates of ICU and hospital discharge, vital status at ICU and hospital discharge, and 28, 60 , and 90 days after ICU admission.

\section{Statistical analyses}

Characteristics of patients were described as frequencies and percentages for categorical variables and as means and standard deviations or medians and interquartile ranges for continuous variables. Categorical variables were compared by Chi-square or Fisher's exact test, and continuous variables were compared by Student's $t$ test or Wilcoxon's rank-sum test. Kaplan-Meier overall survival curves until Day 90 were computed, and were compared using log-rank tests. The median length of stay in ICU and in hospital were also estimated using a KaplanMeier estimator to take into account patients that may be still in ICU at the time of the analysis.

Baseline risk factors of death at Day 90 were assessed within the whole cohort using univariate and multivariate cox regression. Baseline variables (i.e., obtained during the first $24 \mathrm{~h}$ in the ICU) included in the multivariate model were defined a priori, and no variable selection was performed (see the description of the statistical analysis plan in the Supplement). ICU admission dates were split into four calendar periods (i.e., before March, 15; from March 16 to 31; from April 1 to 15; and after April 16). Proportional hazard assumption was assessed by inspecting the scaled Shoenfeld residuals and Harrel's test [15] (Table S4). Multiple imputations were used to replace missing values when appropriate (Figure S1-S2). Ten copies of the dataset were created with the missing values replaced by imputed values, based on observed data including outcomes and baseline characteristics of participants. Each dataset was then analyzed and the results from each dataset were pooled into a final result using Rubin's rule [16]. Lastly, a sensitivity analysis using a Cox model stratified on the center variable was also performed. Hazard ratios and their $95 \%$ confidence interval were estimated. A $p$ value $<0.05$ was considered statistically significant. Statistical analyzes were conducted with R v3.5.1.

\section{Results}

\section{Participating ICUs and Patients Enrolled}

Patients were included in 149 ICUs (71 [48\%] university, 66 [44\%] public regional, and 12 [8\%] private, semi-private, or military hospitals, respectively) from 138 centers in three countries. The median (interquartile) number of ICU beds in these centers and these ICUs were 26 (1855) and 20 (14-28), respectively. Fifty-six percent of the patients were recruited in Paris and the surrounding area (see Table S1-S3 in the Supplement for an extensive description of ICUs and center characteristics). Ninetyfour percent of the centers reported having extended the number of ICU beds during the COVID-19 outbreak.

Of the 4643 patients enrolled on May 4, 2020, 399 were lost to follow-up at Day-90. Thereafter we describe the characteristics of the remaining 4244 patients with available day-90 vital status (Fig. 1).

There were 1085/4244 (26\%) female patients (Table 1). At ICU admission, their median (interquartile) age, SAPS II, and SOFA scores were 63 (54-71) years, $37(28-50)$, and $5(3-8)$, respectively. The rate of obese (BMI $\geq 30 \mathrm{~kg} /$ $\mathrm{m}^{2}$ ) patients was $1607 / 3935(41 \%)$. The most frequent comorbidities were hypertension 2018/4197 (48\%), known diabetes 1167/4196 (28\%), and immunocompromised status 314/4192 (7\%). Median (IQR) time between first symptoms and ICU admission was 9 (6-12) days. Of note, only $176 / 4124$ (4\%) patients were active smokers and only 208/4116 (5\%) had concomitant bacterial pneumonia at ICU admission.

\section{Ventilatory support, adjunctive therapies, and ARDS severity}

On day-1, standard oxygen therapy, high flow oxygen, and non-invasive ventilation were applied to $1219 / 4157$ (29\%), 786/4096 (19\%), and 230/4109 (6\%) patients, respectively. The use of these modalities tended to increase over time (Table S5 and Figure S3). 2635/4175 (63\%) were placed on invasive mechanical ventilation during the first $24 \mathrm{~h}$, whereas in total 3376/4209 (80\%) were intubated during their ICU stay. On the first day 


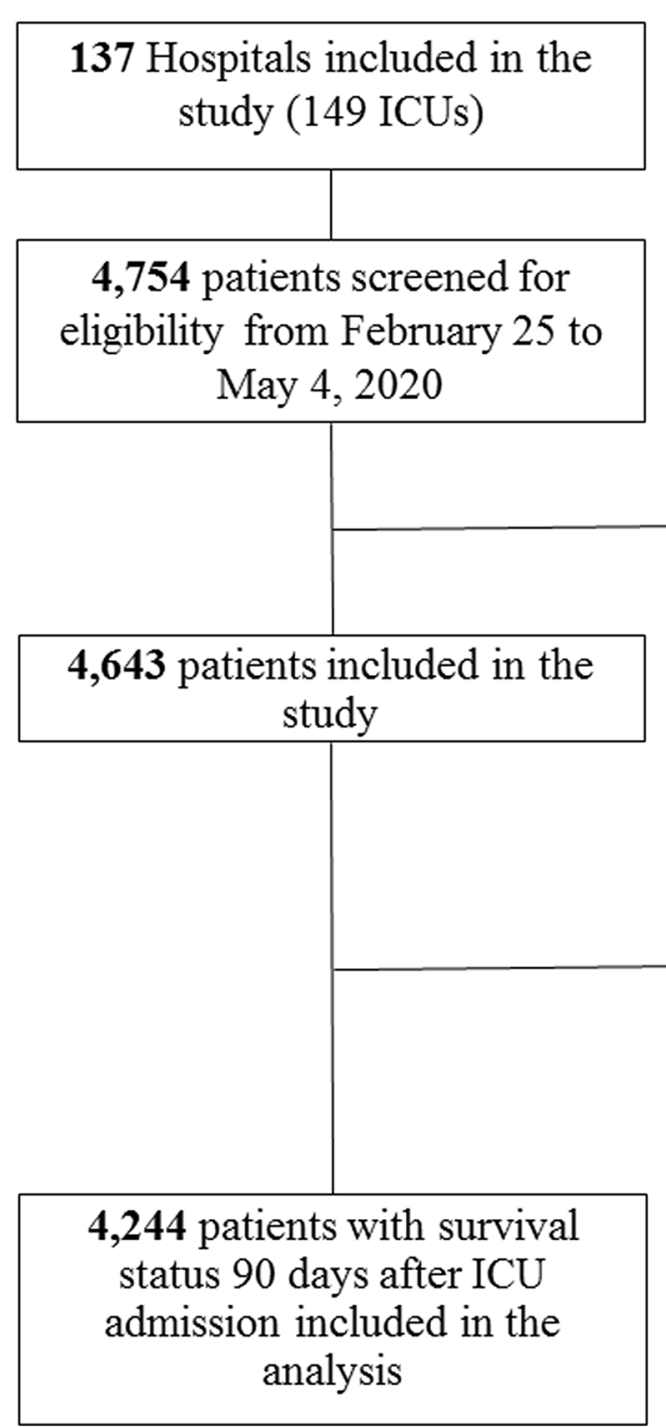

\section{1 excluded}

98 records not finalized

13 other reasons

\section{9 lost to follow-up}

Fig. 1 Flowchart of patients screening and inclusion. ICU intensive care unit

in ICU, median tidal volume, PEEP, plateau, driving pressures, and mechanical power were 6.1 (5.8-6.7) $\mathrm{mL} / \mathrm{kg}, 12(10-14) \mathrm{cmH}_{2} \mathrm{O}, 24(21-27) \mathrm{cmH}_{2} \mathrm{O}, 13$ (10-17) $\mathrm{cmH}_{2} \mathrm{O}$, and $26.5(18.6-34.9) \mathrm{J} / \mathrm{min}$, respectively (Table 1). 1841/2560 (72\%) patients required a $\mathrm{FiO}_{2} \geq 50 \%$, while 1371 (54\%) received a PEEP $\geq 12$ $\mathrm{cmH}_{2} \mathrm{O}$.

Mild, moderate, and severe ARDS was reported in $539 / 2233$ (24\%), 1154/2233 (52\%), and 540/2233 (24\%) patients on mechanical ventilation (invasive or noninvasive) on ICU day 1 , respectively (Table 2). Continuous neuromuscular blockade and prone position were used in 1966/2224 (88\%), and 1556/2223 (70\%) in these patients. Moderate and severe ARDS patients were more likely to receive these adjunct therapies, with a median number of 3 (IQR 2-6) prone positioning sessions per patient. Of note, 888/2224 (41\%) of them received corticosteroids for a median of 5 (IQR 2-8) days. Lastly, 321/4187 (8\%) patients were placed on extracorporeal membrane oxygenation (ECMO). Table 56 provides the use of adjunct therapies in the whole cohort of 4224 patients.

ICU complications and organ support in patients intubated on ICU-day 1

Ventilator-associated pneumonia was diagnosed in $1209 / 2101$ (58\%) patients who were intubated on ICU day 1 , whereas $623 / 2227$ (28\%) patients had an acute kidney failure requiring renal replacement therapy 
Table 1 Demographic, clinical, and ventilatory support characteristics of $\mathbf{4 2 4 4}$ patients according to their $\mathbf{9 0}$-day survival status

\begin{tabular}{|c|c|c|c|c|c|}
\hline & \multirow[t]{2}{*}{ No. } & \multirow{2}{*}{$\begin{array}{l}\text { All patients } \\
(n=4244)\end{array}$} & \multicolumn{2}{|l|}{ 90-day status } & \multirow[t]{2}{*}{$P$ value } \\
\hline & & & Alive $(n=2946)$ & Death $(n=1298)$ & \\
\hline Age, years, & 4244 & $63(54-71)$ & $61(52-69)$ & $68(59-74)$ & $<0.001$ \\
\hline Women, no (\%) & 4226 & $1085(26)$ & $771(26)$ & $314(24)$ & 0.170 \\
\hline Body mass index, $\mathrm{kg} / \mathrm{m}^{2}$ & 3935 & $28(25-32)$ & $29(26-32)$ & $28(25-32)$ & 0.006 \\
\hline$\geq 30 \mathrm{~kg} / \mathrm{m}^{2}$ & & $1607(41)$ & $1167(42)$ & $440(37)$ & 0.004 \\
\hline Active smokers & 4124 & $176(4)$ & $116(4)$ & $60(5)$ & 0.234 \\
\hline SAPS II score & 3935 & $37(28-50)$ & $34(27-46)$ & $44(33-58)$ & $<0.001$ \\
\hline SOFA score at ICU admission & 3676 & $5(3-8)$ & $4(3-8)$ & $7(4-10)$ & $<0.001$ \\
\hline Treated hypertension & 4197 & $2018(48)$ & $1310(45)$ & $708(55)$ & $<0.001$ \\
\hline Known diabetes & 4196 & $1167(28)$ & $704(24)$ & $463(36)$ & $<0.001$ \\
\hline Immunodeficiency ${ }^{\mathrm{a}}$ & 4192 & $314(7)$ & $178(6)$ & $136(11)$ & $<0.001$ \\
\hline Long-term corticosteroids $^{b}$ & 4178 & $178(4)$ & $94(3)$ & $84(7)$ & $<0.001$ \\
\hline Clinical frailty scale & 3152 & $2(2-3)$ & $2(2-3)$ & $3(2-4)$ & $<0.001$ \\
\hline \multicolumn{6}{|l|}{ Time between } \\
\hline First symptoms to ICU admission, days & 4007 & $9(6-12)$ & $9(7-12)$ & $8(5-11)$ & $<0.001$ \\
\hline ICU admission to invasive MV, hours & $2010^{c}$ & $8(1-27)$ & $9(1-27)$ & $7(1-29)$ & 0.482 \\
\hline \multicolumn{6}{|l|}{ During the first $24 \mathrm{~h}$ in ICU } \\
\hline Standard oxygen therapy & 4157 & $1219(29)$ & $927(32)$ & $292(23)$ & $<0.001$ \\
\hline High-flow oxygen & 4096 & $786(19)$ & $584(21)$ & $202(16)$ & $<0.001$ \\
\hline Noninvasive ventilation & 4109 & $230(6)$ & $134(5)$ & $96(8)$ & $<0.001$ \\
\hline Invasive mechanical ventilation & 4175 & $2635(63)$ & $1678(58)$ & $957(75)$ & $<0.001$ \\
\hline $\mathrm{PaO}_{2} / \mathrm{FiO}_{2}$ & 2500 & $154(106-223)$ & $163(116-229)$ & $136(91-206)$ & $<0.001$ \\
\hline $\mathrm{VT}, \mathrm{mL} / \mathrm{kg} \mathrm{PBW}$ & 2306 & $6.1(5.8-6.7)$ & $6.1(5.8-6.6)$ & $6.1(5.7-6.7)$ & 0.652 \\
\hline Set PEEP, $\mathrm{cm} \mathrm{H} \mathrm{H}_{2} \mathrm{O}$ & 2542 & $12(10-14)$ & $12(10-14)$ & $12(10-14)$ & 0.429 \\
\hline Plateau pressure, $\mathrm{CmH}_{2} \mathrm{O}$ & 1847 & $24(21-27)$ & $24(21-26)$ & $25(21-28)$ & $<0.001$ \\
\hline Driving pressure, $\mathrm{cmH}_{2} \mathrm{O}^{\mathrm{d}}$ & 2256 & $13(10-17)$ & $12(10-16)$ & $14(11-18)$ & $<0.001$ \\
\hline Static compliance, $\mathrm{mL} / \mathrm{cmH}_{2} \mathrm{O}^{\mathrm{e}}$ & 1746 & $33(26-42)$ & $34(27-43)$ & $32(24-41)$ & $<0.001$ \\
\hline$<30$ & & $635(36)$ & $367(33)$ & $268(43)$ & $<0.001$ \\
\hline $30-39$ & & $562(32)$ & $380(34)$ & $182(29)$ & \\
\hline$\geq 40$ & & $549(31)$ & $376(33)$ & $173(28)$ & \\
\hline Dynamic compliance, $\mathrm{mL} / \mathrm{cmH}_{2} \mathrm{O}^{f}$ & 409 & $17(14-25)$ & $18(14-26)$ & $17(13-22)$ & 0.010 \\
\hline Mechanical power, J/min ${ }^{9}$ & 1987 & $26.5(18.6-34.9)$ & $26.1(18.4-34.2)$ & $27.1(18.9-36.1)$ & 0.120 \\
\hline Ventilatory ratio ${ }^{h}$ & 2251 & $1.7(1.4-2.2)$ & $1.7(1.4-2.1)$ & $1.8(1.4-2.3)$ & 0.017 \\
\hline Concomitant bacterial pneumonia & 4116 & $208(5)$ & $138(5)$ & $70(6)$ & 0.298 \\
\hline Hemodynamic component of the SOFA, & 4065 & $1(0-4)$ & $0(0-3)$ & $3(0-4)$ & $<0.001$ \\
\hline Renal component of the SOFA, & 4014 & $0(0-1)$ & $0(0-0)$ & $0(0-1)$ & $<0.001$ \\
\hline Corticosteroids $^{i}$ & 4134 & $459(11)$ & $278(10)$ & $181(14)$ & $<0.001$ \\
\hline \multicolumn{6}{|l|}{ Blood gases } \\
\hline $\mathrm{pH}$ & 4003 & $7.41(7.34-7.46)$ & $7.43(7.36-7.47)$ & $7.38(7.30-7.44)$ & $<0.001$ \\
\hline $\mathrm{PaCO}_{2}, \mathrm{mmHg}$ & 4004 & $40(35-46)$ & $39(35-45)$ & $41(35-49)$ & $<0.001$ \\
\hline $\mathrm{PaO}_{2} / \mathrm{FiO}_{2}^{\mathrm{j}}$ & 3080 & $154(103-222)$ & $162(112-227)$ & $134(90-205)$ & $<0.001$ \\
\hline $\mathrm{HCO}_{3}, \mathrm{mmol} / \mathrm{L}$ & 3942 & $25(22-27)$ & $25(23-27)$ & $24(21-27)$ & $<0.001$ \\
\hline Lactate, $\mathrm{mmol} / \mathrm{L}$ & 3795 & $1.2(0.9-1.6)$ & $1.2(0.9-1.5)$ & $1.3(1.0-1.8)$ & $<0.001$ \\
\hline \multicolumn{6}{|l|}{ Biology } \\
\hline Lymphocyte count, $\times 10^{9} / \mathrm{L}$ & 3481 & $0.8(0.6-1.2)$ & $0.8(0.6-1.2)$ & $0.8(0.5-1.1)$ & $<0.001$ \\
\hline Platelet count, $\times 10^{9} / \mathrm{L}$ & 3867 & $224(167-291)$ & $230(176-299)$ & $205(151-271)$ & $<0.001$ \\
\hline Total bilirubin, $\mu \mathrm{mol} / \mathrm{L}$ & 3029 & $10(7-14)$ & $10(7-14)$ & $10(7-16)$ & 0.210 \\
\hline Serum creatinine, $\mu \mathrm{mol} / \mathrm{L}$ & 3915 & $78(61-112)$ & $73(59-98)$ & $94(69-152)$ & $<0.001$ \\
\hline
\end{tabular}


Table 1 (continued)

\begin{tabular}{|c|c|c|c|c|c|}
\hline & \multirow[t]{2}{*}{ No. } & \multirow{2}{*}{$\begin{array}{l}\text { All patients } \\
(n=4244)\end{array}$} & \multicolumn{2}{|l|}{90 -day status } & \multirow[t]{2}{*}{$P$ value } \\
\hline & & & Alive $(n=2946)$ & Death $(n=1298)$ & \\
\hline D-dimers, $\mu \mathrm{g} / \mathrm{L}$ & 1697 & $1600(897-3690)$ & $1450(843-3212)$ & $2200(1127-5516)$ & $<0.001$ \\
\hline
\end{tabular}

Results are expressed as $\mathrm{n}(\%)$ or median (25th-75th percentiles)

$\mathrm{FiO}_{2}$ fraction of inspired oxygen, $\mathrm{HCO}_{3}$ bicarbonate, $\mathrm{PEEP}$ positive end-expiratory pressure, $\mathrm{PaCO}_{2}$ partial pressure of carbon dioxide, $\mathrm{PBW}$ predicted body weight, $\mathrm{PaO}$ partial pressure of oxygen, SAPS simplified acute physiology score, SOFA Sequential Organ Failure Assessment, $V T$ tidal volume

a Defined as hematological malignancies, active solid tumor, or having received specific anti-tumor treatment within a year, solid-organ transplant, human immunodeficiency virus, or immunosuppressants

b Several ventilation modalities could have been used during the first $24 \mathrm{~h}$

c Time of intubation was available for 2010/3376 patients with invasive mechanical ventilation during their ICU stay

${ }^{d}$ Defined as plateau pressure-PEEP; If plateau pressure was missing, peak pressure was considered instead

e Defined as tidal volume/(Plateau pressure - PEEP)

${ }^{f}$ Defined as tidal volume/(Peak pressure - PEEP)

${ }^{9}$ Mechanical power $(\mathrm{J} / \mathrm{min})=0.098 \times$ tidal volume $\times$ respiratory rate $\times($ peak pressure $-1 / 2 \times$ driving pressure). If not specified, peak pressure was considered equal to plateau pressure

${ }^{\mathrm{h}}$ Defined as (minute ventilation $\left.\times \mathrm{PaCO}_{2}\right)-$ (predicted bodyweight $\left.\times 100 \times 37.5\right)$

i Irrespective of the dose and the indication

j Calculated for all patients, including those on oxygen therapy using conversion tables provided in the online supplement

(Table 2). A venous thromboembolic complication was diagnosed in 373/2226 (17\%) patients, of whom 207/2226 (9\%) had proven pulmonary embolism.

\section{Patient outcomes and predictors of 90-day mortality}

Overall 90-day mortality was $31 \%$. Within the first 7 days after ICU admission, 64 (12\%, 95 confidence interval $[\mathrm{CI}], 9-15 \%)$ patients with mild and 183 (16\%, 95 CI 14-18\%) with moderate ARDS progressed to severe ARDS. In patients on mechanical ventilation (invasive or non-invasive) at ICU day one, 90-day mortality was $820 / 2233(37 \%)$, and increased with the severity of ARDS at ICU admission (30\%, 34\% and $50 \%$ in mild, moderate, and severe ARDS patients, respectively) (Table 3 and Fig. 2). 90-day mortality was $292 / 1219$ (24\%), 202/786 (26\%), and 96/230 (42\%) in patients who received standard oxygen therapy, high flow oxygen, or non-invasive ventilation at day1. Noticeably, 90-day mortality declined over time from 42 to $25 \%(p<0.001)$ in the first and the last period, respectively (Table S5 and Figure S3). Of note, 90 -day mortality was $36 \%$ in patients intubated during their ICU stay and $11 \%$ for those not intubated (see Table S7). The overall median durations of mechanical ventilation, ICU, and hospital stay for 90-day survivors were 13 (8-18), 21 (13-36), and 30 (20-48) days, respectively. Of note, these durations increased with the severity of the ARDS (Table 3).

Results of the multivariable analysis are reported in Table 4. After inspection of the proportional hazard assumption, a time-varying effect was introduced in the multivariate Cox model for four variables: body mass index, active smoking, renal component of the SOFA score, and lymphopenia. Thus, for these variables, two types of hazard ratio are reported, indicating the early effect (before 14 days of follow-up) or the late effect (after 15 days of follow-up) of the corresponding baseline characteristic on the risk of death, respectively.

Non-survivors were older, and more frequently diabetic or immunocompromised than survivors. At ICU admission, they had a higher renal and hemodynamic SOFA component scores and lower $\mathrm{PaO}_{2} / \mathrm{FiO}_{2}$ ratio. Interestingly, they also had a shorter time since the onset of the first symptoms. Day-1 patients' characteristics significantly associated with higher 90-day mortality identified by the Cox regression model were older age, known diabetes, class 2 and extreme obesity, immunodeficiency, higher renal and cardiovascular components of the SOFA score, lower $\mathrm{PaO}_{2} / \mathrm{FiO}_{2}$, lower $\mathrm{pH}$, and a shorter time between first symptoms and ICU admission (Table 4). The same analysis re-run after multiple imputations of missing data (Table S8), and a sensitivity analysis introducing the center variable as a stratification variable in the multivariable model yielded similar results (Table S9). Kaplan-Meier survival estimates according to age, ICU admission period, the renal component of the SOFA score, the delay between the first symptoms and ICU admission, immunocompromised status, diabetes, severe lymphopenia, and static pulmonary compliance categories at day-1 are provided in Figs. 2b, S4-S10. Lastly, outcomes of patients who progressed from mild to moderate or severe ARDS and those who progressed from moderate to severe ARDS within the first week of mechanical ventilation are reported in Fig. 2c, d. 
Table 2 Use of adjunct measures, organ dysfunction and major complications according to acute respiratory distress syndrome severity for patients on mechanical ventilation (invasive or non-invasive) on ICU day 1

\begin{tabular}{|c|c|c|c|c|c|c|}
\hline Parameter & No. & $\begin{array}{l}\text { All }{ }^{\mathrm{a}} \\
(n=2233)\end{array}$ & $\begin{array}{l}\text { Mild ARDS } \\
(n=539)\end{array}$ & $\begin{array}{l}\text { Moderate ARDS } \\
(n=1154)\end{array}$ & $\begin{array}{l}\text { Severe ARDS } \\
(n=540)\end{array}$ & $P$ value \\
\hline \multicolumn{7}{|l|}{ Ventilatory features on Day-1 } \\
\hline Plateau pressure, $\mathrm{cmH}_{2} \mathrm{O}$ & 1617 & $24(21-27)$ & $24(21-26)$ & $24(21-27)$ & $25(22-28)$ & $<0.001$ \\
\hline Driving pressure, $\mathrm{cmH}_{2} \mathrm{O}^{\mathrm{e}}$ & 1965 & $13(10-17)$ & $12(10-15)$ & $13(10-18)$ & $14(11-18)$ & $<0.001$ \\
\hline Static compliance, $\mathrm{mL} / \mathrm{cmH}_{2} \mathrm{O}^{\mathrm{f}}$ & 1531 & $33(26-42)$ & $36(29-44)$ & $33(26-42)$ & $30(24-37)$ & $<0.001$ \\
\hline Mechanical power, J/min ${ }^{\mathrm{g}}$ & 1735 & $26.6(18.7-34.9)$ & $24.9(18.3-33.3)$ & $26.4(18.5-34.4)$ & $29.1(20.3-37.6)$ & 0.001 \\
\hline Tracheotomy & 2229 & $198(9)$ & $53(10)$ & $107(9)$ & $38(7)$ & 0.207 \\
\hline Prone position & 2223 & $1556(70)$ & $308(57)$ & $822(71)$ & $426(79)$ & $<0.001$ \\
\hline Number of session & 1553 & $3(2-6)$ & $3(2-6)$ & $3(2-6)$ & $3(2-6)$ & 0.585 \\
\hline Continuous neuromuscular blockers & 2224 & $1966(88)$ & $441(82)$ & $1025(89)$ & $500(93)$ & $<0.001$ \\
\hline Nitric oxide & 2224 & $425(19)$ & $74(14)$ & $206(18)$ & $145(27)$ & $<0.001$ \\
\hline Corticosteroids $^{h}$ & 2224 & $888(41)$ & $192(37)$ & $458(41)$ & $238(46)$ & 0.012 \\
\hline ECMO & 2153 & $235(11)$ & $41(8)$ & $111(10)$ & $83(15)$ & $<0.001$ \\
\hline Cardiac arrest & 2227 & $133(6)$ & $31(6)$ & $58(5)$ & $44(8)$ & 0.038 \\
\hline Thromboembolic complications & 2226 & $373(17)$ & $107(20)$ & $174(15)$ & $92(17)$ & 0.043 \\
\hline Pulmonary embolism & & $207(9)$ & $59(11)$ & $95(8)$ & $53(10)$ & 0.872 \\
\hline Proven distal venous thrombosis & & $184(8)$ & $54(10)$ & $89(8)$ & $41(8)$ & 0.567 \\
\hline Renal replacement therapy & 2227 & $623(28)$ & $135(25)$ & $320(28)$ & $168(31)$ & 0.080 \\
\hline Bacterial coinfection & 1951 & $144(7)$ & $24(5)$ & $84(8)$ & $36(8)$ & 0.062 \\
\hline Ventilator-associated pneumonia & 2101 & $1209(58)$ & $276(54)$ & $628(58)$ & 307 (61) & 0.084 \\
\hline
\end{tabular}

Definition of abbreviations: ECMO extracorporeal membrane oxygenation. Results are expressed as $n$ (\%) or median (25th-75th percentiles)

a Only patients on invasive mechanical ventilation or non-invasive ventilation within the first $24 \mathrm{~h}$ in ICU

b Defined as $200 \mathrm{mmHg}<\mathrm{PaO}_{2} / \mathrm{FIO}_{2} \leq 300 \mathrm{mmHg}$ with $\mathrm{PEEP} \geq 5 \mathrm{~cm} \mathrm{H}_{2} \mathrm{O}$ or continuous positive airway pressure $\geq 5 \mathrm{~cm} \mathrm{H}_{2} \mathrm{O}$

c Defined as $100 \mathrm{mmHg}<\mathrm{PaO}_{2} / \mathrm{FIO}_{2} \leq 200 \mathrm{mmHg}$ with PEEP $\geq 5 \mathrm{~cm} \mathrm{H}_{2} \mathrm{O}$

d Defined as $\mathrm{PaO}_{2} / \mathrm{FIO}_{2} \leq 100 \mathrm{mmHg}$ with $\mathrm{PEEP} \geq 5 \mathrm{~cm} \mathrm{H}_{2} \mathrm{O}$

e Defined as plateau pressure-PEEP; If plateau pressure was missing, peak pressure was considered instead

${ }^{f}$ Defined as tidal volume/(plateau pressure - PEEP)

$g$ Mechanical power $(\mathrm{J} / \mathrm{min})=0.098 \times$ tidal volume $\times$ respiratory rate $\times$ (peak pressure $-1 / 2 \times$ driving pressure). If not specified, peak pressure was considered equal to plateau pressure

h Irrespective of the indication, the dose, and the timing

\section{Discussion}

We report herein one of the largest prospective caseseries of COVID-19 patients who required intensive care admission, with detailed information on their baseline characteristics, ARDS severity, and 90-day outcomes. Overall 90 -day mortality was $31 \%$ and was higher in older and obese patients, diabetics, immunocompromised patients, and those who had multiple organ dysfunction at ICU admission. 90-day mortality rates were $30 \%, 34 \%$, and $50 \%$, in patients with mild, moderate, and severe ARDS who were on mechanical ventilation (invasive or non-invasive) on ICU day-1, respectively. Noticeably, mortality rates decreased over time during the study period, while ICU and hospital length of stay were substantially longer than in other cohorts of ARDS patients [17].

Acute respiratory failure was the main indication for ICU admission, with $80 \%$ of our COVID-19 patients requiring invasive mechanical ventilation which is consistent with the experience in Lombardy, Italy [2], where $88 \%$ of ICU patients were intubated. However, lower rates of intubation in ICU patients were reported in Wuhan, China by Wang et al. (47\%), and Yang et al. (42\%) $[18,19]$, and in Washington state, USA (71\%) [20]. While early single-center reports in small groups of COVID patients reported well-preserved lung mechanics despite the severity of hypoxemia [21], more recent data [22] and our observations suggested that lung compliance and driving pressure were close to those of reported in classical ARDS. Mechanical power which is the energy delivered to the respiratory system over time during mechanical ventilation was very high in our patients with ARDS, reaching 26.5 (18.6-34.9) J/ min, while a higher mortality risk has been suggested for patients with ARDS whose value exceeded $17 \mathrm{~J} / \mathrm{min}$ [23]. In that context, the application of evidence-based 
Table 3 Outcome of patients on mechanical ventilation (invasive or non-invasive) according to Acute Respiratory Distress Syndrome Severity assessed the first day in the ICU

\begin{tabular}{|c|c|c|c|c|c|c|}
\hline Parameter & No. & $\begin{array}{l}\text { All } \\
(n=2233)\end{array}$ & $\begin{array}{l}\text { Mild ARDS } \\
(n=539)\end{array}$ & $\begin{array}{l}\text { Moderate ARDS } \\
(n=1154)\end{array}$ & $\begin{array}{l}\text { Severe ARDS }{ }^{d} \\
(n=540)\end{array}$ & $P_{\text {value }}{ }^{e}$ \\
\hline $\begin{array}{l}\text { Progression of ARDS severity, No } \\
\text { (\%) }[95 \mathrm{CI}]\end{array}$ & 2233 & 2233 & $\begin{array}{l}539 \\
(24)[22-26]\end{array}$ & $\begin{array}{l}1154 \\
(52)[50-54]\end{array}$ & $\begin{array}{l}540 \\
(24)[22-26]\end{array}$ & \\
\hline Progression to moderate ${ }^{c}$ & & & $\begin{array}{l}237 \\
(44)[40-48]\end{array}$ & - & - & \\
\hline Progression to severe ${ }^{d}$ & & & $\begin{array}{l}64 \\
(12)[9-15]\end{array}$ & $\begin{array}{l}183 \\
(16)[14-18]\end{array}$ & - & \\
\hline $\begin{array}{l}\text { Duration of invasive ventilation, } \\
\text { days }\end{array}$ & 1448 & & & & & \\
\hline All patients & & $12(7-17)$ & $11(6-17)$ & $12(7-17)$ & $11(6-17)$ & 0.021 \\
\hline Surviving patients at day-90 & & $13(8-18)$ & $12(6-18)$ & $14(8-18)$ & $14(10-19)$ & 0.007 \\
\hline ICU length of stay, days & 2187 & & & & & \\
\hline All patients & & $16(9-28)$ & $15(8-27)$ & $17(9-28)$ & $16(8-30)$ & 0.149 \\
\hline Surviving patients at day-90 & & $21(13-36)$ & $18(10-31)$ & $21(13-35)$ & $26(16-43)$ & $<0.001$ \\
\hline ICU mortality & 2214 & $773(35)$ & $146(27)$ & $366(32)$ & $261(49)$ & $<0.001$ \\
\hline Hospital length of stay, days & 2041 & & & & & \\
\hline All patients & & $23(12-39)$ & $22(13-39)$ & $24(13-40)$ & $22(9-36)$ & 0.002 \\
\hline Surviving patients at day- 90 & & $30(20-48)$ & $28(17-47)$ & $31(20-47)$ & $32(23-49)$ & 0.012 \\
\hline Hospital mortality & 2086 & $797(38)$ & $154(30)$ & $375(35)$ & $268(53)$ & $<0.001$ \\
\hline Still in the hospital at day- 28 & & $1152(53)$ & $286(54)$ & $628(56)$ & $238(45)$ & $<0.001$ \\
\hline Day-28 mortality & 2233 & $703(31)$ & $134(25)$ & $331(29)$ & $238(44)$ & $<0.001$ \\
\hline Day-60 mortality & 2233 & $808(36)$ & $157(29)$ & $382(33)$ & $269(50)$ & $<0.001$ \\
\hline Day-90 mortality & 2233 & $820(37)$ & $162(30)$ & $388(34)$ & $270(50)$ & $<0.001$ \\
\hline
\end{tabular}

Results are expressed as $n$ (\%) or median (25th-75th percentiles)

ARDS acute respiratory distress syndrome, ICU intensive care unit

a Only patients on invasive mechanical ventilation or non-invasive ventilation within the first $24 \mathrm{~h}$ in the ICU

b Defined as $200 \mathrm{mmHg}<\mathrm{PaO}_{2} / \mathrm{FIO}_{2} \leq 300 \mathrm{mmHg}$ with PEEP $\geq 5 \mathrm{~cm} \mathrm{H}_{2} \mathrm{O}$ or continuous positive airway pressure $\geq 5 \mathrm{~cm} \mathrm{H}_{2} \mathrm{O}$

c Defined as $100 \mathrm{mmHg}<\mathrm{PaO}_{2} / \mathrm{FlO}_{2} \leq 200 \mathrm{mmHg}$ with PEEP $\geq 5 \mathrm{~cm} \mathrm{H}_{2} \mathrm{O}$

d Defined as $\mathrm{PaO}_{2} / \mathrm{FIO}_{2} \leq 100 \mathrm{mmHg}$ with $\mathrm{PEEP} \geq 5 \mathrm{~cm} \mathrm{H}_{2} \mathrm{O}$

e $p$ global value

ARDS care, such as lung-protective mechanical ventilation and proning are both warranted [24]. ECMO, which was used in $15 \%$ of severe ARDS in our cohort should be considered when these measures have failed [25].

28-day mortality was $39 \%$ in 257 critically-ill COVID19 patients in New-York city, of whom 203 (79\%) received invasive mechanical ventilation [4], $41 \%$ in patients on invasive mechanical ventilation included in the usual care group of the RECOVERY randomized trial [6] and $>50 \%$ in 733 Chinese patients admitted in the ICU [3]. Despite similar severity at baseline, day-28 mortality were $26 \%$ in the whole cohort and $30 \%$ in our patients intubated at day-1, a rate close to that reported in the large LUNG-SAFE study [17]. Different characteristics of patients admitted to ICUs and different degrees of stress on healthcare systems could explain these discrepancies [26]. Besides, we report a progressive decrease in 90-day mortality over the study period with a higher proportion of patients on high flow oxygen and non-invasive ventilation and a lower rate of intubation on ICU day-1 in the last period of the study (Table S5 and Figure S3). Similar findings have been reported by other groups [27] and might reflect better knowledge of the pathophysiology of the disease over time and less reluctance to use non-invasive oxygenation strategies. It should however be noticed that duration of invasive mechanical ventilation and length of ICU and hospital stays were substantially longer than those of in ARDS unrelated to COVID-19. For instance, ICU length of stay in patients surviving severe ARDS was 26 (13-43) days, compared to 14 (7-23) days in the LUNG-SAFE study [17]. These patients rapidly overwhelmed ICU's capacity, forcing a major reorganization of ICU beds during the crisis [28].

Identifying the determinants of outcomes of critically ill patients with severe COVID-19 is crucial to optimize 


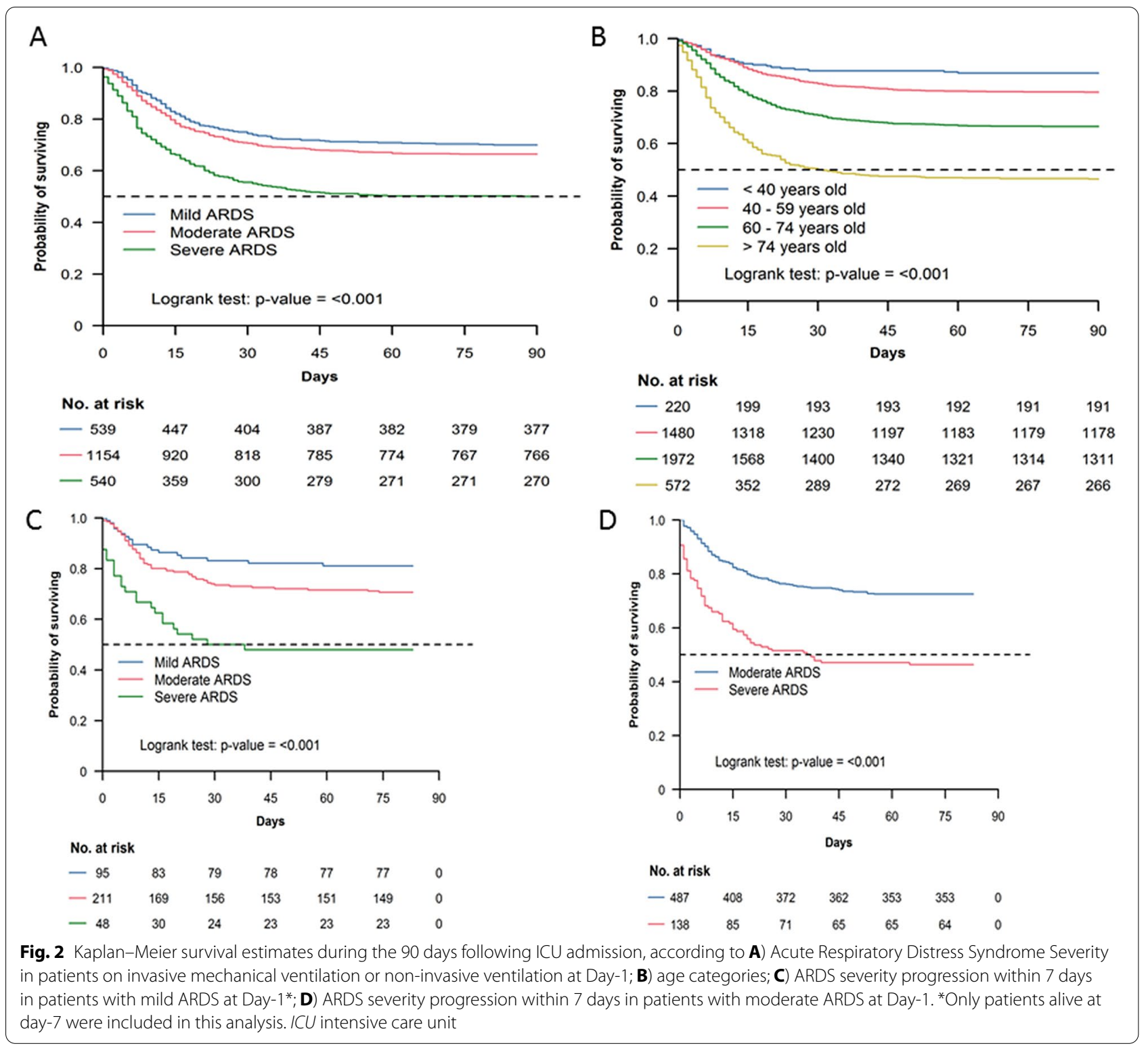

the use of ICU care and other hospital resources. Older age, obesity, diabetes, being immunocompromised, lower $\mathrm{PaO}_{2} / \mathrm{FiO}_{2}$ and higher hemodynamic and renal SOFA score at ICU admission were independently associated with 90-day mortality, highlighting the dismal impact of premorbid conditions and multiorgan damage on the outcomes of patients with the most severe forms of COVID-19 [3, 29]. The rate of patients with a BMI $\geq 30 \mathrm{~kg} / \mathrm{m}^{2}$ ) was $41 \%$ in our cohort and unusually high compared to the prevalence of obesity in the French population [30]. More severe COVID-19 in obese patients may be explained by impairments in the adaptive immune response [31], cardiometabolic and thrombotic derangements [32], and alterations in lung function [33].
Obesity may also be a marker of poorer baseline health conditions since it is frequently associated with a lower socio-economic status [34]. As previously reported [35], a shorter time between first symptoms and ICU admission was also independently associated with increased mortality. Lastly, we and others [36, 37] observed an unusually high rate of thromboembolic complications, with 9\% of proven pulmonary embolism. This rate may likely be higher since pulmonary CT angiography was not systematically performed in all patients. Diffuse vascular endothelium injury and intense activation of the coagulation cascade may explain this increased risk of venous thrombosis [38]. 
Table 4 Predictive patient factors associated with 90-day mortality in critically ill adults with COVID-19

\begin{tabular}{|c|c|c|c|c|c|}
\hline & No. & Univariate HR $(95 \% \mathrm{CI})$ & $P$ value & Multivariate $\mathrm{HR}(95 \% \mathrm{Cl})^{\mathrm{a}}$ & $P$ value \\
\hline Age, years & 4244 & $1.05(1.04-1.05)$ & $<0.001$ & $1.05(1.04-1.06)$ & $<0.001$ \\
\hline Date of ICU admission & 4244 & & $<0.001$ & & 0.311 \\
\hline Before March, 15 & & - & & - & \\
\hline From March, 16 to 31 & & $0.69(0.56-0.84)$ & & $0.86(0.64-1.16)$ & \\
\hline From April, 1 to 15 & & $0.61(0.50-0.76)$ & & $0.75(0.54-1.04)$ & \\
\hline After April, 16 & & $0.54(0.40-0.72)$ & & $0.82(0.52-1.29)$ & \\
\hline Immunodeficiency & 4192 & $1.64(1.38-1.96)$ & $<0.001$ & $1.38(1.06-1.80)$ & 0.020 \\
\hline Body mass index, $\mathrm{kg} / \mathrm{m}^{2 b}$ & 3935 & & 0.013 & & 0.007 \\
\hline$<25$ & & - & & - & \\
\hline \multirow[t]{2}{*}{$25 \leq \mathrm{BMl}<30$} & & $0.92(0.68-1.25)$ & & $1.06(0.78-1.43)$ & \\
\hline & & $0.77(0.57-1.03)$ & & $0.81(0.60-1.10)$ & \\
\hline \multirow[t]{2}{*}{$30 \leq \mathrm{BMI}<35$} & & $0.94(0.68-1.29)$ & & $1.11(0.80-1.55)$ & \\
\hline & & $0.59(0.42-0.83)$ & & $0.63(0.44-0.89)$ & \\
\hline \multirow[t]{2}{*}{$35 \leq \mathrm{BMI}<40$} & & $1.16(0.79-1.69)$ & & $1.50(1.02-2.21)$ & \\
\hline & & $0.49(0.30-0.79)$ & & $0.60(0.37-0.97)$ & \\
\hline \multirow[t]{2}{*}{$\geq 40$} & & $1.47(0.93-2.33)$ & & $2.05(1.28-3.27)$ & \\
\hline & & $0.60(0.32-1.14)$ & & $0.87(0.45-1.66)$ & \\
\hline \multirow[t]{2}{*}{ Active smoking $^{b}$} & 3935 & $1.51(0.96-2.36)$ & 0.225 & $1.30(0.82-2.05)$ & 0.314 \\
\hline & & $0.87(0.45-1.70)$ & & $0.71(0.36-1.39)$ & \\
\hline Treated hypertension & 4197 & $1.44(1.29-1.60)$ & $<0.001$ & $1.01(0.85-1.19)$ & 0.940 \\
\hline Known diabetes & 4196 & $1.62(1.44-1.81)$ & $<0.001$ & $1.51(1.28-1.78)$ & $<0.001$ \\
\hline Time between first symptoms to ICU admission, days & 3862 & & $<0.001$ & & 0.010 \\
\hline$<4$ days & & - & & - & \\
\hline 4-7 days & & $0.87(0.65-1.16)$ & & $1.07(0.80-1.43)$ & \\
\hline$\geq 8$ days & & $0.52(0.39-0.70)$ & & $0.73(0.54-0.98)$ & \\
\hline \multicolumn{6}{|l|}{ During the first $24 \mathrm{~h}$ in the ICU } \\
\hline CV component of the SOFA score $\geq 3$ & 4065 & $1.77(1.58-1.98)$ & $<0.001$ & $1.79(1.52-2.11)$ & $<0.001$ \\
\hline \multirow[t]{2}{*}{ Renal component of the SOFA score $\geq 3^{b}$} & 4014 & $3.01(2.30-3.92)$ & $<0.001$ & $2.38(1.81-3.13)$ & $<0.001$ \\
\hline & & $1.66(1.11-2.48)$ & & $1.32(0.87-2.01)$ & \\
\hline Coagulation component of the SOFA score $\geq 3$ & 4002 & $2.01(1.21-3.34)$ & 0.016 & $1.73(0.81-3.69)$ & 0.190 \\
\hline $\mathrm{PaO}_{2} / \mathrm{FiO}_{2}^{\mathrm{C}}$ & 3080 & & $<0.001$ & & $<0.001$ \\
\hline $200<\mathrm{PaO}_{2} / \mathrm{FiO}_{2} \leq 300$ & & $0.94(0.72-1.21)$ & & $0.93(0.67-1.29)$ & \\
\hline $100<\mathrm{PaO}_{2} / \mathrm{FiO}_{2} \leq 200$ & & $1.09(0.87-1.38)$ & & $1.12(0.83-1.51)$ & \\
\hline $\mathrm{PaO}_{2} / \mathrm{FiO}_{2} \leq 100$ & & $1.73(1.36-2.19)$ & & $2.05(1.51-2.78)$ & \\
\hline \multirow[t]{2}{*}{ Lymphocyte count $\leq 1 \times 10^{9} / \mathrm{L}^{\mathrm{b}}$} & 3481 & $0.92(0.75-1.14)$ & 0.008 & $0.80(0.65-0.99)$ & 0.030 \\
\hline & & $1.46(1.14-1.88)$ & & $1.24(0.96-1.60)$ & \\
\hline $\mathrm{pH}$ & 4003 & $0.67(0.60-0.75)$ & $<0.001$ & $0.80(0.65-0.97)$ & 0.065 \\
\hline
\end{tabular}

The major strength of this study is the detailed report of physiological, clinical features, ventilatory management, and 90-day outcomes of a large, multicenter series of 4244 critically ill COVID-19 patients. We acknowledge several limitations to our study. First, we conducted this cohort at a time where the national health system was extremely pressured with a need for a large number of
ICU beds in some regions. Then, we cannot rule out that ICU admission policies and patients' management were similar in all centers, although a sensitivity analysis introducing the center variable in the multivariable model found similar results. Second, testing was not standardized across sites, which might have led to misclassification. Third, some variables have missing data (as reported 
in the tables) due to a large number of patients included in a short period and intense clinical activity during the crisis. Indeed, our multivariable model included only $51 \%$ of the whole cohort of patients because of these missing data, which may explain, together with other residual confounders, the unanticipated lower mortality before 14 days of follow-up associated with baseline lymphopenia $[39,40]$. However, this association was no longer statistically significant in the model with multiple imputations. Fourth, Grasselli et al. recently reported that high D-dimer concentration was significantly associated with mortality in COVID-19-related ARDS patients when associated with low values of static respiratory system compliance [22]. Unfortunately, we were unable to confirm that result in our multivariable model due to inconsistent collection of this data at ICU admission.

\section{Conclusions}

In this case series of 4244 critically ill patients with laboratory-confirmed COVID-19 admitted to our ICUs, overall 90 -day mortality was $31 \%$ and decreased over time during the study period. Mortality was higher in older patients, immunocompromised, extreme obese, diabetics, those with a shorter delay between first symptoms and ICU admission, and those with extra-pulmonary organ dysfunction at ICU admission. Ninety-day mortality increased with the severity of ARDS from $30 \%$ in mild to $50 \%$ in severe ARDS. These information, together with the very long durations of mechanical ventilation and of ICU stay, which have contributed to the swamping of our ICU's capacity, will be critical for the management of the second wave of the epidemic. Lastly, long-term follow-up is warranted to provide a complete description of the outcomes and potential sequelae associated with the most severe forms of COVID-19 requiring ICU treatment.

\section{Electronic supplementary material}

The online version of this article (https://doi.org/10.1007/s00134-020-06294-x) contains supplementary material, which is available to authorized users.

\section{Acknowledgements}

We acknowledge with gratitude all the French, Belgian, and Swiss clinical research centers, the medical students, the students of the Polytechnic University, and all the volunteers for their amazing help in data collection.

Role of the funder: The funder had no role in the design and conduct of the study, collection, management, analysis, and interpretation of the data; preparation, review, or approval of the manuscript; and decision to submit the manuscript for publication.

Participating sites and COVID-ICU investigators: CHU Angers, Angers, France (Alain Mercat, Pierre Asfar, François Beloncle, Julien Demiselle), APHP - Hôpital Bicêtre, Le Kremlin-Bicêtre, France (Tài Pham, Arthur Pavot, Xavier Monnet, Christian Richard), APHP-Hôpital Pitié Salpêtrière, Paris, France (Alexandre Demoule, Martin Dres, Julien Mayaux, Alexandra Beurton), CHU Caen Normandie-Hôpital Côte de Nacre, Caen, France, Cédric Daubin (Richard Descamps, Aurélie Joret, Damien Du Cheyron), APHP-Hôpital Cochin, Paris, France (Frédéric Pene, Jean-Daniel Chiche, Mathieu Jozwiak, Paul Jaubert), APHP-Hôpital Tenon, Paris (France, Guillaume Voiriot, Muriel Fartoukh, Marion
Teulier, Clarisse Blayau), CHRU de Brest-La Cavale Blanche, Brest, France (Erwen L'Her, Cécile Aubron, Laetitia Bodenes, Nicolas Ferriere), Centre Hospitalier de Cholet, Cholet, France (Johann Auchabie, Anthony Le Meur, Sylvain Pignal, Thierry Mazzoni), CHU Dijon Bourgogne, Dijon, France (Jean-Pierre Quenot, Pascal Andreu, Jean-Baptiste Roudau, Marie Labruyère), CHU Lille-Hôpital Roger Salengero, Lille, France (Saad Nseir, Sébastien Preau, Julien Poissy, Daniel Mathieu), Groupe Hospitalier Nord Essonne, Longjumeau, France (Sarah Benhamida, Rémi Paulet, Nicolas Roucaud, Martial Thyrault), APHM-Hopital Nord, Marseille, France (Florence Daviet, Sami Hraiech, Gabriel Parzy, Aude Sylvestre), Hôpital de Melun-Sénart, Melun, France (Sébastien Jochmans, Anne-Laure Bouilland, Mehran Monchi), Élément Militaire de Réanimation du SSA, Mulhouse, France (Marc Danguy des Déserts, Quentin Mathais, Gwendoline Rager, Pierre Pasquier), CHU Nantes-Hôpital Hotel Dieu, Nantes, France (Reignier Jean, Seguin Amélie, Garret Charlotte, Canet Emmanuel), CHU Nice-Hôpital Archet, Nice, France (Jean Dellamonica, Clément Saccheri, Romain Lombardi, Yanis Kouchit), Centre Hospitalier d'Orléans, Orléans, France (Sophie Jacquier, Armelle Mathonnet, Mai-Ahn Nay, Isabelle Runge), Centre Hospitalier Universitaire de la Guadeloupe, Pointe-à-Pitre, France (Frédéric Martino, Laure Flurin, Amélie Rolle, Michel Carles), Hôpital de la Milétrie, Poitiers, France (Rémi Coudroy, Arnaud W Thille, Jean-Pierre Frat, Maeva Rodriguez), Centre Hospitalier Roanne, Roanne, France (Pascal Beuret, Audrey Tientcheu, Arthur Vincent, Florian Michelin), CHU Rouen-Hôpital Charles Nicolle, Rouen, France (Marie Anne Melone, Maxime Gauzi, Arnaud Guilbert, Geoffrey Kouadri), CHRU Tours-Hôpital Bretonneau, Tours, France (Valérie Gissot, Stéphan Ehrmann, Charlotte Salmon-Gandonniere, Djlali Elaroussi), Centre Hospitalier Bretagne Atlantique, Vannes, France (Agathe Delbove, Yannick Fedun, Julien Huntzinger, Eddy Lebas), CHU Liège, Liège, Belgique (Grâce Kisoka, Céline Grégoire, Stella Marchetta, Bernard Lambermont), Hospices Civils de Lyon-Hôpital Edouard Herriot, Lyon, France (Laurent Argaud, Thomas Baudry, Pierre-Jean Bertrand, Auguste Dargent), Centre Hospitalier Du Mans, Le Mans, France (Christophe Guitton, Nicolas Chudeau, Mickaël Landais, Cédric Darreau), Centre Hospitalier de Versailles, Le Chesnay, France (Alexis Ferre, Antoine Gros, Guillaume Lacave, Fabrice Bruneel), Hôpital Foch, Suresnes, France (Mathilde Neuville, Jérome Devaquet, Guillaume Tachon, Richard Gallot), Hôpital Claude Galien, Quincy sous Senart, France (Riad Chelha, Arnaud Galbois, Anne Jallot, Ludivine Chalumeau Lemoine), GHR Mulhouse Sud-Alsace, Mulhouse, France (KhaldounKuteifan, Valentin Pointurier, Louise-Marie Jandeaux, Joy Mootien), APHP-Hôpital Antoine Béclère, Clamart, France (Charles Damoisel, Benjamin Sztrymf), APHP-Hôpital Pitié-Salpêtrière, Paris, France (Matthieu Schmidt, Alain Combes, Juliette Chommeloux, Charles Edouard Luyt), Hôpital Intercommunal de Créteil, Créteil, France (Frédérique Schortgen, Leon Rusel, Camille JUNG), Hospices Civils de Lyon-Hôpital Neurologique, Lyon, France (Florent Gobert), APHP-Hôpital Necker, Paris, France (Damien Vimpere, Lionel Lamhaut), Centre Hospitalier Public du Cotentin-Hôpital Pasteur, Cherbourg-en-cotentin, France (Bertrand Sauneuf, Liliane Charrier, Julien Calus, Isabelle Desmeules), CHU Rennes-Hôpital du Pontchaillou, Rennes, France (Benoît Painvin, Jean-Marc Tadie), CHU Strasbourg-Hôpital Hautepierre, Strasbourg, France (Vincent Castelain, Baptiste Michard, Jean-Etienne Herbrecht, Mathieu Baldacini), APHP-Hôpital Pitié Salpêtrière, Paris, France (Nicolas Weiss, Sophie Demeret, Clémence Marois, Benjamin Rohaut), Centre Hospitalier Territorial GastonBourret, Nouméa, France (Pierre-Henri Moury, Anne-Charlotte Savida, Emmanuel Couadau, Mathieu Série), Centre Hospitalier Compiègne-Noyon, Compiègne, France (Nica Alexandru), Groupe Hospitalier Saint-Joseph, Paris, France (Cédric Bruel, Candice Fontaine, Sonia Garrigou, Juliette Courtiade Mahler), Centre hospitalier mémorial de Saint-Lô, Saint-Lô, France (Maxime Leclerc, Michel Ramakers), Grand Hôpital de l'Est Francilien, Jossigny, France (Pierre Garçon, Nicole Massou, Ly Van Vong, Juliane Sen), Gustave Roussy, Villejuif, France (Nolwenn Lucas, Franck Chemouni, Annabelle Stoclin), Centre Hospitalier Intercommunal Robert Ballanger, Aulnay-sous-Bois, France (Alexandre Avenel, Henri Faure, Angélie Gentilhomme, Sylvie Ricome), Hospices Civiles de Lyon-Hôpital Edouard Herriot, Lyon, France (Paul Abraham, Céline Monard, Julien Textoris, Thomas Rimmele), Centre Hospitalier d'Avignon, Avignon, France (Florent Montini), Groupe Hospitalier DiaconessesCroix Saint Simon, Paris, France (Gabriel Lejour, Thierry Lazard, Isabelle Etienney, Younes Kerroumi), CHU Clermont-Ferrand-Hôpital Gabriel Montpied, Clermont Ferrand, France (Dupuis Claire, MarinBereiziat, Elisabeth Coupez, Thouy François), Hôpital d'Instruction des Armées Percy, Clamart, France (Clémet Hoffmann, Nicolas Donat, Violaine Muller, Thibault Martinez), CHU Nancy-Hôpital Brabois, Vandoeuvre-les-Nancy, France (Antoine Kimmoun, Audrey Jacquot, Matthieu Mattei, Bruno Levy), Centre Hospitalier de Vichy, 
Vichy, France (Ramin Ravan, Loïc Dopeux, Jean-Mathias Liteaudon, Delphine Roux), Hopital Pierre Bérégovoy, Nevers, France (Brice Rey, Radu Anghel, Deborah Schenesse, Vincent Gevrey), Centre Hospitalier de Tarbes, Tarbes, France (Jermy Castanera, Philippe Petua, Benjamin Madeux), Hôpitaux Civils de Colmar-Hôpital Louis pasteur, Colmar, France (Otto Hartman), CHU CharleroiHôpital Marie Curie, Bruxelles, Belgique (Michael Piagnerelli, Anne Joosten, Cinderella Noel, Patrick Biston), Centre hospitalier de Verdun Saint Mihiel, Saint Mihiel, France (Thibaut Noel), CH Eure-Seine-Hôpital d'EvreuxVernon, Evreux, France (Gurvan LE Bouar, Messabi Boukhanza, Elsa Demarest, Marie-France Bajolet), Hôpital René Dubos, Pontoise, France (Nathanaël Charrier, Audrey Quenet, Cécile Zylberfajn, Nicolas Dufour), APHP-Hôpital Lariboisière, Paris, France (BunoMégarbane, Sqébastian Voicu, Nicolas Deye, Isabelle Malissin), Centre Hospitalier de Saint-Brieuc, Saint-Brieuc, France (François Legay, Matthieu Debarre, Nicolas Barbarot, Pierre Fillatre), Polyclinique Bordeaux Nord Aquitaine, Bordeaux, France (Bertrand Delord, Thomas Laterrade, Tahar Saghi, Wilfried Pujol), HIA Sainte Anne, Toulon, France (Pierre Julien Cungi, Pierre Esnault, Mickael Cardinale), Grand Hôpital de l'Est Francilien, Meaux, France (Vivien Hong Tuan Ha, Grégory Fleury, Marie-Ange Brou, Daniel Zafimahazo), HIA Robert Picqué, Villenave d'Ornon, France (David Tran-Van, Patrick Avargues, Lisa Carenco), Centre Hospitalier Fontainebleau, Fontainebleau, France (Nicolas Robin, Alexandre Ouali, Lucie Houdou), Hôpital Universitaire de Genève, Genève, Suisse (Christophe Le Terrier, Noémie Suh, Steve Primmaz, JéromePugin), APHP-Hôpital Beaujon, Clichy, France (Emmanuel Weiss, Tobias Gauss, Jean-Denis Moyer, Catherine Paugam-Burtz) Groupe Hospitalier Bretage Sud, Lorient, France (Béatrice La Combe, Rolland Smonig, Jade Violleau, Pauline Cailliez), Centre Hospitalier Intercommunal Toulon, La Seyne sur Mer, France (Jonathan Chelly), Centre Hospitalier de Dieppe, Dieppe, France (Antoine Marchalot, Cécile Saladin, Christelle Bigot), CHU de Martinique, Fort-de-France, France (Pierre-Marie Fayolle, Jules Fatséas, Amr Ibrahim, DaborResiere), Hôpital Fondation Adolphe de Rothchild, Paris, France (Rabih Hage, Clémentine Cholet, Marie Cantier, Pierre Trouiller), APHP-Bichat Claude Bernard, Paris, France (Philippe Montravers, Brice Lortat-Jacob, Sebastien Tanaka, Alexy Tran-Dinh), APHP-Hôpital Universitaire Paris Sud, Bicêtre, France (Jacques Duranteau, Anatole Harrois, Guillaume Dubreuil, Marie Werner), APHP-Hôpital Européen Georges Pompidou, Paris, France (Anne Godier, Sophie Hamada, Diane Zlotnik, Hélène Nougue), APHP, GHU Henri Mondor, Créteil, France (Armand Mekontso-Dessap, Guillaume Carteaux, Keyvan Razazi, Nicolas De Prost), APHP-Hôpitaux Universitaires Henri Mondor, Créteil, France (Nicolas Mongardon, Olivier Langeron, Eric Levesque, Arié Attias), APHP-Hôpital Lariboisière, Paris, France (Charles de Roquetaillade, Benjamin G. Chousterman, Alexandre Mebazaa, Etienne Gayat), APHP-Hôpital Saint-Antoine, Paris, France (Marc Garnier, Emmanuel Pardo, LeaSatre-Buisson, Christophe Gutton), APHP Hôpital Saint-Louis, Paris, France (Elise Yvin, Clémence Marcault, Elie Azoulay, Michael Darmon), APHP-Hopital Avicennes (Nicolas Bonnet, Nathan Ebstein, Stéphane Gaudry, Yves Cohen), APHP-Hôpital Saint-Antoine, Paris, France (Hafid Ait Oufella, Geoffroy Hariri, Tomas Urbina, Sandie Mazerand), APHP-Hôpital Raymond Pointcarré, Garches, France (Nicholas Heming, Francesca Santi, Pierre Moine, DjillaliAnnane), APHP-Hôpital Pitié Salpêtrière, Paris, France (Adrien Bouglé, Edris Omar, Aymeric Lancelot, Emmanuelle Begot), Centre Hospitalier Victor Dupouy, Argenteuil, France (Gaétan Plantefeve, Damien Contou, Hervé Mentec, Olivier Pajot), CHU Toulouse-Hôpital Rangueil, Toulouse, France (Stanislas Faguer, Olivier Cointault, Laurence Lavayssiere, Marie-Béatrice Nogier), Centre Hospitalier de Poissy, Poissy, France (Matthieu Jamme, Claire Pichereau, Jan Hayon, Hervé Outin), APHP-HôpitalSaint-Louis, Paris, France (François Dépret, Maxime Coutrot, Maité Chaussard, Lucie Guillemet), Clinique du MontLégia, CHC Groupe-Santé, Liège, Belgique (Pierre Goffin, Romain Thouny, Julien Guntz, Laurent Jadot), CHU Saint-Denis, La Réunion, France (Romain Persichini), Centre Hospitalier de Tourcoing, Tourcoing, France (Vanessa Jean-Michel, Hugues Georges, Thomas Caulier), Centre Hospitalier Henri Mondor d'Aurillac, Aurillac, France (Gaël Pradel, Marie-Hélène Hausermann, ThiMy Hue Nguyen-Valat, Michel Boudinaud), Centre Hospitalier Saint Joseph Saint Luc, Lyon, France (Emmanuel Vivier, SylvèneRosseli, Gaël Bourdin, Christian Pommier) Centre Hospitalier de Polynésie Française, Polynésie, France (Marc Vinclair, Simon Poignant, Sandrine Mons), Ramsay Générale de Santé, Hôpital Privé Jacques Cartier, Massy, France (Wulfran Bougouin), Centre Hospitalier Alpes Léman, Contamine sur Arve, France (Franklin Bruna, Quentin Maestraggi, Christian Roth), Hospices Civils de Lyon-Hôpital de la Croix Rousse, Lyon, France (Laurent Bitker, François Dhelft, Justine Bonnet-Chateau, Mathilde Filippelli), Centre Cardiologique du Nord, Saint-Denis, France (Tristan Morichau-Beauchant, Stéphane Thierry, Charlotte Le Roy, Mélanie Saint Jouan),
GHU-Hôpital Saint-Anne, Paris, France (Bruno Goncalves, Aurélien Mazeraud, Matthieu Daniel, Tarek Sharshar) CHR Metz-Hôpital Mercy, Metz, France (Cyril Cadoz, Rostane Gaci, Sébastien Gette, Guillaune Louis), APHP-Hôpital Paul Brousse, Villejuif, France (Sophe-Caroline Sacleux, Marie-Amélie Ordan), CHRU Nancy-Hôpital Central, Nancy, France (Aurélie Cravoisy, Marie Conrad, Guilhem Courte, Sébastien Gibot), Centre Hospitalier d'Ajaccio, Ajaccio, France (Younès Benzidi, Claudia Casella, Laurent Serpin, Jean-Lou Setti), Centre Hospitalier de Bourges, Bourges, France (Marie-Catherine Besse, Anna Bourreau), Centre hospitalier de la Côte Basque, Bayonne, France (Jérôme Pillot, Caroline Rivera, Camille Vinclair, Marie-Aline Robaux), Hospices Civils de Lyon-Hôpital de la Croix Rousse, Lyon, France (Chloé Achino, Marie-Charlotte Delignette, Tessa Mazard, Frédéric Aubrun), CH Saint-Malo, Saint-Malo, France (Bruno Bouchet, Aurélien Frérou, Laura Muller, Charlotte Quentin), Centre Hospitalier de Mulhouse, Mulhouse, France (Samuel Degoul), Centre Hospitalier de Briançon, Briançon, France (Xavier Stihle, Claude Sumian, Nicoletta Bergero, Bernard Lanaspre), CHU Nice, Hôpital Pasteur 2, Nice, France (Hervé Quintard, Eve Marie Maiziere), Centre Hospitalier des Pays de Morlaix, Morlaix, France (Pierre-Yves Egreteau, Guillaume Leloup, Florin Berteau, Marjolaine Cottrel), Centre Hospitalier Valence, Valence, France (Marie Bouteloup, Matthieu Jeannot, Quentin Blanc, Julien Saison), Centre Hospitalier Niort, Niort, France (Isabelle Geneau, Romaric Grenot, Abdel Ouchike, Pascal Hazera), APHP-Hôpital Pitié Salpêtrière, Paris, France (Anne-Lyse Masse, Suela Demiri, Corinne Vezinet, Elodie Baron, Déborah Benchetrit, Antoine Monsel), Clinique du Val d'Or, Saint Cloud, France (Grégoire Trebbia, Emmanuelle Schaack, Raphaël Lepecq, Mathieu Bobet), Centre Hospitalier de Béthune, Béthune, France (Christophe Vinsonneau, Thibault Dekeyser, Quentin Delforge, Imen Rahmani), Groupe Hospitalier Intercommunal de la Haute-Saône, Vesoul, France (Bérengère Vivet, Jonathan Paillot, Lucie Hierle, Claire Chaignat, Sarah Valette), Clinique Saint-Martin, Caen, France (BenoïtHer, Jennifier Brunet), Ramsay Générale de Santé, Clinique Convert, Bourg en Bresse, France (Mathieu Page, Fabienne Boiste, Anthony Collin), Hôpital Victor Jousselin, Dreux, France(Florent Bavozet, Aude Garin,Mohamed Dlala, KaisMhamdi), Centre Hospitalier de Troye, Troye, France, (Bassem Beilouny, Alexandra Lavalard, Severine Perez), CHU de ROUEN-Hôpital Charles Nicolle, Rouen, France (Benoit Veber, Pierre-Gildas Guitard, Philippe Gouin, Anna Lamacz), Centre Hospitalier Agen-Nérac, Agen, France (Fabienne Plouvier, Bertrand P delaborde, AïssaKherchache, Amina Chaalal), APHP-Hôpital Louis Mourier, Colombes, France (Jean-Damien Ricard, Marc Amouretti, Santiago Freita-Ramos, Damien Roux), APHP-Hôpital Pitié-Salpêtrière, Paris, France (Jean-Michel Constantin, Mona Assefi, Marine Lecore, Agathe Selves), Institut Mutualiste Montsouris, Paris, France (Florian Prevost, Christian Lamer, Ruiying Shi, Lyes Knani), CHU Besançon-Hôpital Jean Minjoz, Besançon, France, Sébastien Pili-Floury, Lucie Vettoretti), APHP-Hôpital Universitaire Robert-Debré, Paris, France (Michael Levy, Lucile Marsac, Stéphane Dauger, Sophie Guilmin-Crépon), CHU Besançon-Hôpital Jean Minjoz, Besançon, France, Hadrien Winiszewski, Gael Piton, Thibaud Soumagne, Gilles Capellier, Médipôle Lyon-Villeurbanne, Vileurbanne, France, (Jean-Baptiste Putegnat, Frédérique Bayle, Maya Perrou, Ghyslaine Thao), APHP-Ambroise Paré, Boulogne-Billancourt, France (Guillaume Géri, Cyril Charron, Xavier Repessé, Antoine Vieillard-Baron), CHU Amiens Picardie, Amiens, France (Mathieu Guilbart, Pierre-Alexandre Roger, Sébastien Hinard, Pierre-Yves Macq), Hôpital Nord-Ouest, Villefranche-surSaône, France (Kevin Chaulier, Sylvie Goutte), CH de Châlons en Champagne, Châlons en Champagne, France (Patrick Chillet, Anaïs Pitta, Barbara Darjent, Amandine Bruneau), CHU Angers, Angers, France (Sigismond Lasocki, Maxime Leger, Soizic Gergaud, Pierre Lemarie), CHU Grenoble Alpes, Grenoble, France (Nicolas Terzi, Carole Schwebel, Anaïs Dartevel, Louis-Marie Galerneau), APHP-Hôpital Européen Georges Pompidou, Paris, France (Jean-Luc Diehl, Caroline Hauw-Berlemont, Nicolas Péron, Emmanuel Guérot), Hôpital Privé d'Antony, Antony, France (AbolfazlMohebbiAmoli, Michel Benhamou, Jean-Pierre Deyme, Olivier Andremont), Institut Arnault Tzanck,Saint Laurent du Var, France (Diane Lena, Julien Cady, Arnaud Causeret, Arnaud De La Chapelle), Centre Hospitalier d'Angoulême, Angoulême, France (Christophe Cracco, Stéphane Rouleau, David Schnell),Centre Hospitalier de Cahors, Cahors, France (Camille Foucault), Centre hospitalier de Carcassonne, Carcassonne, France (Cécile Lory), CHU Nice-Hôpital L'Archet 2, Nice, France (Thibault Chapelle, Vincent Bruckert, Julie Garcia, Abdlazize Sahraoui), Hôpital Privé du Vert Galant, Tremblay-en-France, France (Nathalie Abbosh, Caroline Bornstain, Pierre Pernet), Centre Hospitalier de Rambouillet, Rambouillet, France (Florent Poirson, Ahmed Pasem, Philippe Karoubi), Hopitaux du Léman, Thonon les Bains, France (Virginie Poupinel, Caroline Gauthier, François Bouniol, Philippe Feuchere), Centre Hospitalier Victor Jousselin, Dreux, France 
(Florent Bavozet, Anne Heron), Hôpital Sainte Camille, Brie sur Marne, France (Serge Carreira, Malo Emery, Anne Sophie Le Floch, Luana Giovannangeli), Hôpital d'instruction des armées Clermont-Tonnerre, Brest, France (Nicolas Herzog, Christophe Giacardi, Thibaut Baudic, Chloé Thill), APHP-Hôpital Pitié Salpêtrière, Paris, France (Said Lebbah, Jessica Palmyre, Florence Tubach, David Hajage), groupement hospitalier Ré Aunis, La Rochelle (Olivier Lesieur, Julie Noublanche), Centre Hospitalier Départemental de Vendée La-Roche-Sur-Yon, France (Gwenhaël Colin, Jean-Claude Lacherade, Gauthier Bionz, Natacha Maquigneau), Centre Hospitalier Intercommunal de Mont de Marsan et du Pays des Sources, Mont de Marsan, France (Arnaud Sément, Isabel Roca-Cerezo, Michel Pascal, Nesrine Sma).

Management and Writing Committee: Matthieu Schmidt, MD, PhD, Sorbonne Université, Institute of Cardiometabolism and Nutrition, APHP, PitiéSalpêtrière Hospital, Medical Intensive Care Unit, Paris, France; David Hajage, MD, PhD, Sorbonne Université, INSERM, Institut Pierre Louis d'Epidémiologie et de Santé Publique, AP-HP, Département de Santé Publique, Centre de Pharmacoépidémiologie, Paris, France; Alexandre Demoule, MD, PhD, Sorbonne Université, INSERM, UMRS1 158, AP-HP, Groupe Hospitalier Universitaire APHPSorbonne Université, Medical Intensive Care Unit and Respiratory Division; Tài Pham, MD, PhD, Service de Médecine Intensive-Réanimation, Hôpital Bicêtre, AP-HP, Université Paris-Saclay, Le Kremlin-Bicêtre; Alain Combes MD, PhD, Sorbonne Université, Institute of Cardiometabolism and Nutrition, APHP, PitiéSalpêtrière Hospital, Medical Intensive Care Unit, Paris, France; Martin Dres, MD, PhD, Sorbonne Université, INSERM, UMRS1158, AP-HP, Groupe Hospitalier Universitaire APHP-Sorbonne Université, Medical Intensive Care Unit and Respiratory Division; Said Lebbah, MD, AP-HP, Unité de Recherche Clinique Pitié Salpêtrière Charles Foix, Paris, France; Antoine Kimmoun, MD, PhD, Université de Lorraine, CHRU de Nancy, Service de Médecine Intensive et Réanimation Brabois, INSERM U1116, Vandoeuvre-les-Nancy, France; Alain Mercat, MD, PhD, Département de Médecine Intensive-Réanimation et Médecine Hyperbare, Centre Hospitalier Universitaire d'Angers, Université d'Angers, France; Gaëtan Beduneau, MD, Normandie Univ, UNIROUEN, EA 3830, Rouen UniversityHospital, Medical Intensive care Unit, F-76,000 Rouen, France; Jessica Palmyre, Sorbonne Université, INSERM, Institut Pierre Louis d'Epidémiologie et de Santé Publique, AP-HP, Département de Santé Publique, Centre de Pharmacoépidémiologie, Paris, France. Margot Prevost, Sorbonne Université, INSERM, Institut Pierre Louis d'Epidémiologie et de Santé Publique, AP-HP, Département de Santé Publique, Centre de Pharmacoépidémiologie, Paris, France.

\section{Author contributions}

MS and DH had full access to all of the data in the study and takes responsibility for the integrity of the data and the accuracy of the data analysis. Concept and design: GB, AC, AD, MD, DH, AK, AM, TP, MS. Methodology: DH. Acquisition, analysis, or interpretation of data: $A C, A D, M D, D H, A K, A M, T P, M S$. Drafting of the manuscript: $A C, A D, D H, M S$, Critical revision of the manuscript for important intellectual content: GB, MD, AK, AM, TP. Statistical analysis: DH, SL. Supervision: AC, AD, AM. Obtained funding: AD, DH, JP, MS. Administrative, technical, or material support: JP, FP.

\section{Funding}

This study was funded by the Fondation AP-HP and the Direction de la Recherche Clinique et du Developpement and the French Ministry of Health. The REVA network received a 75,000 € research grant form Air Liquide Healthcare. Sponsor: The sponsor was Assistance Publique Hôpitaux de Paris (AP-HP).

\section{Compliance with ethical standrads}

\section{Conflicts of interest}

MS reported personal fees from Getinge, Drager, and Xenios, outside the submitted work. AD reports personal fees from Medtronic, grants, personal fees and non-financial support from Philips, personal fees from Baxter, personal fees from Hamilton, personal fees and non-financial support from Fisher \& Paykel, grants from French Ministry of Health, personal fees from Getinge, grants and personal fees from Respinor, grants and non-financial support from Lungpacer, outside the submitted work. AM reported personal fees from Faron Pharmaceuticals, Air Liquid Medical Systems, Pfizer, Resmed and Draeger and grants and personal fees from Fisher and Paykel and Covidien, outside this work. MD reported personal fees from Lungpacer. AK reported personal fees from Aspen, Aguettant and MSD. No other disclosures were reported.

\section{Publisher's Note}

Springer Nature remains neutral with regard to jurisdictional claims in published maps and institutional affiliations.

Received: 6 July 2020 Accepted: 12 October 2020

Published online: 29 October 2020

\section{References}

1. REVA network http://www.reseau-reva.org/. Accessed 5 Oct 2020

2. Grasselli G, Zangrillo A, Zanella A et al (2020) Baseline characteristics and outcomes of 1591 patients infected with SARS-CoV-2 admitted to ICUs of the Lombardy Region, Italy. JAMA. https://doi.org/10.1001/ jama.2020.5394

3. Xie J, Wu W, Li S et al (2020) Clinical characteristics and outcomes of critically ill patients with novel coronavirus infectious disease (COVID-19) in China: a retrospective multicenter study. Intensive Care Med. https://doi. org/10.1007/s00134-020-06211-2

4. Cummings MJ, Baldwin MR, Abrams D et al (2020) Epidemiology, clinical course, and outcomes of critically ill adults with COVID-19 in New York City: a prospective cohort study. Lancet. https://doi.org/10.1016/ S0140-6736(20)31189-2

5. Grasselli G, Greco M, Zanella A et al (2020) Risk factors associated with mortality among patients with COVID-19 in intensive care units in Lombardy. JAMA Intern Med, Italy. https://doi.org/10.1001/jamaintern med.2020.3539

6. RECOVERY Collaborative Group, Horby P, Lim WS et al (2020) Dexamethasone in hospitalized patients with Covid-19-preliminary report. N Engl J Med. https://doi.org/10.1056/NEJMoa2021436

7. Clinical management of severe acute respiratory infection when COVID-19 is suspected. https://www.who.int/publications-detail/clini cal-management-of-severe-acute-respiratory-infection-when-novel -coronavirus-(ncov)-infection-is-suspected. Accessed 27 Apr 2020

8. Le Gall JR, Lemeshow S, Saulnier F (1993) A new Simplified Acute Physiology Score (SAPS II) based on a European/North American multicenter study. JAMA 270:2957-2963

9. Vincent JL, Moreno R, Takala J et al (1996) The SOFA (Sepsis-related Organ Failure Assessment) score to describe organ dysfunction/failure. On behalf of the Working Group on Sepsis-Related Problems of the European Society of Intensive Care Medicine. Intensive Care Med 22:707-710

10. Juma S, Taabazuing M-M, Montero-Odasso M (2016) Clinical frailty scale in an acute medicine unit: a simple tool that predicts length of stay. Can Geriatr J 19:34-39. https://doi.org/10.5770/cgj.19.196

11. Gattinoni L, Tonetti T, Cressoni M et al (2016) Ventilator-related causes of lung injury: the mechanical power. Intensive Care Med 42:15671575. https://doi.org/10.1007/s00134-016-4505-2

12. Sinha P, Calfee CS, Beitler JR et al (2018) Physiological analysis and clinical performance of the ventilatory ratio in acute respiratory distress syndrome. Am J Respir Crit Care Med. https://doi.org/10.1164/ rccm.201804-06920C

13. Definition Task Force ARDS, Ranieri VM, Rubenfeld GD et al (2012) Acute respiratory distress syndrome: the Berlin Definition. JAMA 307:2526-2533. https://doi.org/10.1001/jama.2012.5669

14. Vincent J-L, Rello J, Marshall J et al (2009) International study of the prevalence and outcomes of infection in intensive care units. JAMA 302:2323-2329. https://doi.org/10.1001/jama.2009.1754

15. Grambsch PM, Therneau TM (1994) Proportional hazards tests and diagnostics based on weighted residuals. Biometrika 81:515-526. https ://doi.org/10.1093/biomet/81.3.515

16. Sterne JAC, White IR, Carlin JB et al (2009) Multiple imputation for missing data in epidemiological and clinical research: potential and pitfalls. BMJ 338:b2393. https://doi.org/10.1136/bmj.b2393

17. Bellani G, Laffey JG, Pham T et al (2016) Epidemiology, patterns of care, and mortality for patients with acute respiratory distress syndrome in intensive care units in 50 countries. JAMA 315:788-800. https://doi. org/10.1001/jama.2016.0291 
18. Wang D, Hu B, Hu C et al (2020) Clinical Characteristics of 138 hospitalized patients with 2019 novel coronavirus-infected pneumonia in Wuhan, China. JAMA. https://doi.org/10.1001/jama.2020.1585

19. Yang $X, Y u Y, X u$ J et al (2020) Clinical course and outcomes of critically ill patients with SARS-CoV-2 pneumonia in Wuhan, China: a singlecentered, retrospective, observational study. Lancet Respir Med. https ://doi.org/10.1016/S2213-2600(20)30079-5

20. Arentz M, Yim E, Klaff L et al (2020) Characteristics and outcomes of 21 critically ill patients with COVID-19 in Washington State. JAMA. https:// doi.org/10.1001/jama.2020.4326

21. Gattinoni L, Chiumello D, Caironi P et al (2020) COVID-19 pneumonia: different respiratory treatments for different phenotypes? Intensive Care Med 46:1099-1102. https://doi.org/10.1007/s00134-020-06033-2

22. Grasselli G, Tonetti T, Protti A et al (2020) Pathophysiology of COVID19-associated acute respiratory distress syndrome: a multicentre prospective observational study. Lancet Respir Med. https://doi. org/10.1016/S2213-2600(20)30370-2

23. Serpa Neto A, Deliberato RO, Johnson AEW et al (2018) Mechanical power of ventilation is associated with mortality in critically ill patients: an analysis of patients in two observational cohorts. Intensive Care Med 44:1914-1922. https://doi.org/10.1007/s00134-018-5375-6

24. Gattinoni L, Meissner K, Marini JJ (2020) The baby lung and the COVID-19 era. Intensive Care Med 46:1438-1440. https://doi.org/10.1007/s0013 4-020-06103-5

25. Schmidt M, Hajage D, Lebreton G et al (2020) Extracorporeal membrane oxygenation for severe acute respiratory distress syndrome associated with COVID-19: a retrospective cohort study. Lancet Respir Med. https:// doi.org/10.1016/S2213-2600(20)30328-3

26. Millar JE, Busse R, Fraser JF et al (2020) Apples and oranges: internationa comparisons of COVID-19 observational studies in ICUs. Lancet Respir Med. https://doi.org/10.1016/S2213-2600(20)30368-4

27. Auld SC, Caridi-Scheible M, Robichaux C et al (2020) Declines in mortality over time for critically ill adults with coronavirus disease 2019. Crit Care Med. https://doi.org/10.1097/CCM.0000000000004687

28. Alban A, Chick SE, Dongelmans DA et al (2020) ICU capacity management during the COVID-19 pandemic using a process simulation. Intensive Care Med 46:1624-1626. https://doi.org/10.1007/s00134-020-06066 $-7$

29. Gabarre P, Dumas G, Dupont T et al (2020) Acute kidney injury in critically ill patients with COVID-19. Intensive Care Med 46:1339-1348. https://doi. org/10.1007/s00134-020-06153-9
30. https://www.santepubliquefrance.fr/les-actualites/2017/etude-esteban2014-2016-chapitre-corpulence-stabilisation-du-surpoids-et-de-l-obesi te-chez-l-enfant-et-I-adulte. Accessed 5 Oct 2020

31. Green WD, Beck MA (2017) Obesity impairs the adaptive immune response to influenza virus. Ann Am Thorac Soc 14:S406-S409. https:// doi.org/10.1513/AnnalsATS.201706-447AW

32. Chait A, den Hartigh LJ (2020) Adipose tissue distribution, inflammation and its metabolic consequences, including diabetes and cardiovascular disease. Front Cardiovasc Med 7:22. https://doi.org/10.3389/ fcrm.2020.00022

33. Gong MN, Bajwa EK, Thompson BT, Christiani DC (2010) Body mass index is associated with the development of acute respiratory distress syndrome. Thorax 65:44-50. https://doi.org/10.1136/thx.2009.117572

34. McLaren L (2007) Socioeconomic status and obesity. Epidemiol Rev 29:29-48. https://doi.org/10.1093/epirev/mxm001

35. Azoulay E, Fartoukh M, Darmon M et al (2020) Increased mortality in patients with severe SARS-CoV-2 infection admitted within seven days of disease onset. Intensive Care Med. https://doi.org/10.1007/s00134-02006202-3

36. Poissy J, Goutay J, Caplan M et al (2020) Pulmonary embolism in COVID19 patients: awareness of an increased prevalence. Circulation. https:// doi.org/10.1161/CIRCULATIONAHA.120.047430

37. Helms J, Tacquard C, Severac F et al (2020) High risk of thrombosis in patients with severe SARS-CoV-2 infection: a multicenter prospective cohort study. Intensive Care Med. https://doi.org/10.1007/s00134-02006062-X

38. Tang N, Li D, Wang X, Sun Z (2020) Abnormal coagulation parameters are associated with poor prognosis in patients with novel coronavirus pneumonia. J Thromb Haemost 18:844-847. https://doi.org/10.1111/jth.14768

39. Liu Z, Long W, Tu M et al (2020) Lymphocyte subset (CD4 +, CD8 +) counts reflect the severity of infection and predict the clinical outcomes in patients with COVID-19. J Infect 81:318-356. https://doi.org/10.1016/j. jinf.2020.03.054

40. Zhou F, Yu T, Du R et al (2020) Clinical course and risk factors for mortality of adult inpatients with COVID-19 in Wuhan, China: a retrospective cohort study. Lancet 395:1054-1062. https://doi.org/10.1016/S0140 $-6736(20) 30566-3$ 